\title{
Osteolipoma: A Rare Variant of the Common Lipoma
}

Emilio Villanueva III ${ }^{1}$ and Ariel Vergel de Dios ${ }^{2}$

${ }^{1}$ Department of Laboratories, University of the Philippines-Philippine General Hospital

${ }^{2}$ Department of Pathology, University of the Philippines-College of Medicine

A 78-year-old female consulted for a ten-year gradually enlarging, right medial thigh mass, measuring $40 \times 40 \times 30 \mathrm{~cm}$ at time of consult. Physical examination shows right lower extremity external rotation, left lower extremity genu varum, and difficulty in walking due to mass effect. No imaging procedures was done; the patient was immediately scheduled for surgery after preoperative clearance. Excision of the thigh mass was performed to relieve the patient of the mass effect. Intraoperative finding was a fibro-fatty mass located in the medial compartment of the thigh. There was no attachment to the femur nor the major blood vessels. The mass was submitted for histopathologic examination.

Gross examination shows yellow to cream/yellow, ovoid, fibrofatty to firm tissue with cream/white to cream/yellow smooth, glistening cut sections, with patchy areas of calcifications and fibrosis. Histopathologic examination shows mature adipose tissue with admixed mature lamellar bone (Figure 1) and areas with hyaline cartilage undergoing ossification (Figure 2). The adipocytes are monotonous and monomorphic. There is no nuclear atypia, lipoblasts, mitotic activity, nor necrosis seen. The case was signed out as osteolipoma.

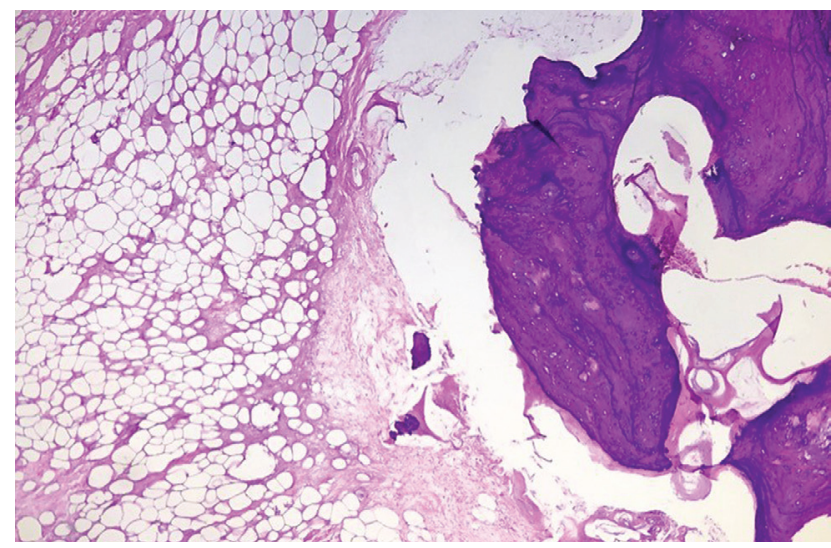

Figure 1. Mature adipose tissue with admixed mature lamellar bone (Hematoxylin and Eosin at 40x).

ISSN 2507-8364 (Online)

Printed in the Philippines.

Copyright $(2017$ by the PJP.

Received: 12 July 2017.

Accepted: 29 July 2017.

Published online first:

https://doi.org/10.21141/PJP.2017.016

Corresponding author: Emilio Q. Villanueva III, MD, RMT, $M T(A S C P i)$

E-mail:drevilthird@gmail.com

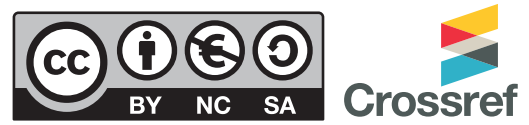

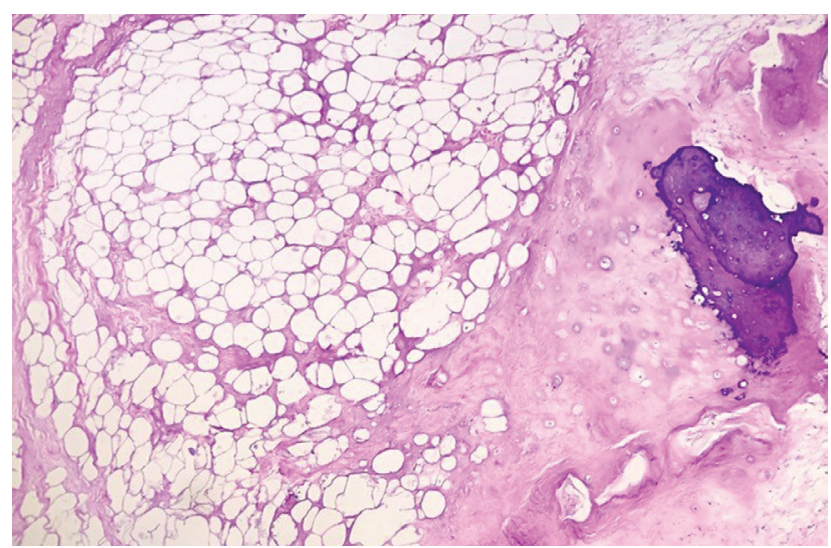

Figure 2. Mature adipose tissue with hyaline cartilage undergoing ossification (Hematoxylin and Eosin at 40x). 
Lipomas are the most common benign soft tissue tumor occurring in subcutaneous tissues. Most patients are adults in 30's to 40's. It is comprised of mature adipocytes without atypia. ${ }^{1,2}$ Variants of lipomas exist, having other mesenchymal components such as fibrous, smooth muscle, myeloid, chondral, vascular, or osseous tissue present admixed with the adipocytes. The nomenclature of the different variants depends on the type of tissue admixed with the adipocyte such as fibrolipoma, leiomyolipoma, myelolipoma, chondrolipoma, angiolipoma, and osteolipoma, respectively. ${ }^{2}$ The rare variant osteolipoma is composed of mature lamellar bone interspersed within the adipose tissue. ${ }^{3}$ Microscopically, they appear as predominantly mature adipose tissues with irregularly distributed mature lamellar bone with areas of ossification. This is the main morphologic criteria of the diagnosis. ${ }^{4}$

The principal pathologic differential diagnosis of a deep-seated lipoma is a well-differentiated liposarcoma. It is a deep-seated tumor common in adults above 50 years old. Morphologically, it is also composed of mature adipocytes. It is differentiated by the presence of scattered hyperchromatic nuclei, mostly situated within the fibrous septa. ${ }^{5}$

There are two main theories regarding the pathogenesis of osteolipoma: first, they may be directly derived from multipotent mesenchymal cells; ${ }^{2}$ another, they may arise after repetitive trauma, ischemia, or metabolic changes initiating osseous metaplasia. The adipose tissue component strengthens this osteoblastic activity. ${ }^{4,6}$

Osteolipomas have good prognosis similar with simple lipoma. Surgical excision is the recommended treatment. ${ }^{1,4}$

\section{REFERENCES}

1. Cheng S, Lu SC, Zhang B, Xue Z, Wang HW. Rare massive osteolipoma in the upper part of the knee in a young adult. Orthopedics. 2012;35(9):e1434-7. PMID: 22955415. https://doi.org/10.3928/01477447-20120822-35.

2. Demiralp B, Alderete JF, Kose O, Ozcan A, Cicek I, Basbozkurt M. Osteolipoma independent of bone tissue: a case report. Cases J. 2009;2:8711. PMID: 19918398. PMCID: PMC2769468. https://doi.org/10.4076/17571626-2-8711.

3. Fritchie KJ, Renner JB, Rao KW, Esther RJ. Osteolipoma: radiological, pathological, and cytogenetic analysis of three cases. Skeletal Radiol. 2012;41(2):237-44. PMID: 21822651. https://doi.org/10.1007/s00256-011-1241-0.

4. Electricwala AJ, Panchwagh Y, Electricwala JT. Giant osteolipoma fixed to the greater trochanter of the femur in a seventy-year-old elderly woman. Cureus. 2017;9(2):e1036. PMID: 28357168. PMCID: PMC5356992. https://doi. org/10.7759/cureus.1036.

5. Fisher C, Montgomery EA, Thway K. Biopsy interpretation of soft tissue tumors. Philadelphia: Lippincott Williams \& Wilkins, 2011

6. Heffernan EJ, Lefaivre K, Munk PL, Nielsen TO, Masri BA. Ossifying lipoma of the thigh. Br J Radiol. 2008;81(1968):e207-10. PMID: 18628326. https://doi. org/10.1259/bjr/38805072.

\footnotetext{
Disclaimer: This journal is OPEN ACCESS, providing immediate access to its content on the principle that making research freely available to the public supports a greater global exchange of knowledge. As a requirement for submission to the PJP, all authors have accomplished an AUTHOR FORM, which declares that the ICMJE criteria for authorship have been met by each author listed, that the article represents original material, has not been published, accepted for publication in other journals, or concurrently submitted to other journals, and that all funding and conflicts of interest have been declared. Consent forms have been secured for the publication of information about patients or cases; otherwise, authors have declared that all means have been exhausted for securing consent.
} 